\title{
Maturational Effects of Glucocorticoids on Neonatal Brush-Border Membrane Phosphate Transport
}

\author{
MAZEN ARAR, MOSHE LEVI, AND MICHEL BAUM \\ Department of Pediatrics [M.A., M.B.] and Internal Medicine [M.L., M.B.], The University of Texas \\ Southwestern Medical Center at Dallas, and the Veterans Administration Medical Center, Dallas, Texas 75235
}

\begin{abstract}
Previous studies have implicated glucocorticoids as an important factor in the postnatal maturational increase in proximal tubule volume absorption, $\mathrm{Na}^{+} / \mathrm{H}^{+}$ antiporter, $\mathrm{Na}\left(\mathrm{HCO}_{3}\right)_{3}$ symporter, and $\mathrm{Na}^{+}-\mathrm{K}^{+}-\mathrm{ATPase}$ activity. The present study examined whether glucocorticoids are also a potentially important factor in the maturational decrease in proximal tubule phosphate transport. Renal BBMs were prepared from neonatal rabbits who received dexamethasone $(10 \mu \mathrm{g} / 100 \mathrm{~g}$ body weight) or vehicle. Brush-border membrane vesicles from dexamethasone-treated neonates had a lower rate of $\mathrm{Na}$-phosphate cotransport than controls $(50.8 \pm 3.6$ versus $29.2 \pm 2.6$ pmol ${ }^{32} \mathrm{P}_{\mathrm{V}} / \mathbf{1 0} \mathrm{s} / \mathrm{mg}$ protein, $\left.p<0.001\right)$. This decrease was due to a decrease in the $V_{\max }$ with no change in the affinity of the transporter for phosphate. The dexamethasoneinduced decrease in BBM Na-phosphate transport was not due to a reduction in transporters as assayed by phosphateprotectable $\mathrm{Na}$-dependent equilibrium binding of phosphonoformic acid. Dexamethasone treatment caused an increase in the fluorescence anisotropy of 1,6-diphenyl1,3,5-hexatriene and trimethylammonium-1,6-diphenyl1,3,5-hexatriene (i.e. a decrease in membrane fluidity). Brush-border membranes from dexamethasone-treated neonates had a decrease in sphingomyelin and an increase in phosphatidylcholine and phosphatidylinositol content but no change in cholesterol or total phospholipid content. These data are consistent with glucocorticoids playing a role in the postnatal maturational decrease in proximal tubule phosphate transport by altering membrane characteristics. (Pediatr Rẹs 35: 474-478, 1994)
\end{abstract}

\section{Abbreviations}

BBM, brush-border membrane DPH, 1,6-diphenyl-1,3,5-hexatriene TMA, trimethylammonium PFA, phosphonoformic acid BLM, basolateral membrane $\mathbf{P}_{\text {, }}$ phosphate

The neonatal proximal tubule has a lower rate of volume reabsorption than the proximal tubule from adult animals (1-3). This overall lower rate of solute transport by the neonatal prox-

Received April 6, 1993; accepted December 7, 1993.

Correspondence and reprint requests: Michel Baum, M.D., Department of Pediatrics, UT Southwestern Medical Center, 5323 Harry Hines Blvd., Dallas, TX $75235-9063$.

Supported by National Institutes of Health Grant DK-41612 (M.B.) and Veterans Administration Research Service (M.L.). imal tubule is due, in part, to a lower rate of glucose transport (2-4) and bicarbonate transport $(2,3)$ by the immature segment. The rate of apical sodium-glucose cotransport (4), $\mathrm{Na}^{+} / \mathrm{H}^{+}$antiporter activity (5-7) and $\mathrm{H}^{+}$-ATPase activity (6), and basolateral $\mathrm{Na}^{+}-\mathrm{K}^{+}$-ATPase $(1,8-10)$ and $\mathrm{Na}\left(\mathrm{HCO}_{3}\right)_{3}$ symporter (5) activity are all significantly less than that in the mature proximal tubule.

Substantial evidence exists that unlike the proximal tubule transport processes described above, renal phosphate transport is higher in neonates than adult animals. Fractional reabsorption of phosphate is higher in infants than in older children (11). Maximal tubular reabsorption of phosphate per volume glomerular filtration rate is higher in neonatal rats than in adult rats, a difference that persists after thyroparathyroidectomy (12-14). There is also direct evidence that the higher rate of phosphate reabsorption by the neonate is due in part to a higher intrinsic rate of phosphate reabsorption by the neonatal kidney $(15,16)$. Neonatal guinea pig kidneys perfused in vitro had a higher maximal tubular reabsorption of phosphate per glomerular filtration rate than adult kidneys (15). In addition, neonatal guinea pig BBM vesicles had a higher $V_{\max }$ for phosphate uptake than those from adult animals (16).

The plasma glucocorticoid concentration rises in the perinatal period (17-19). This rise in glucocorticoid concentration likely plays an important role in the postnatal maturation of the proximal tubule $(1-3,7,8)$. Neonates given glucocorticoids have an increase in proximal tubule $\mathrm{Na}^{+}-\mathrm{K}^{+}$-ATPase activity $(1,3,8$, 9). Fetal rabbits whose mothers were given $50 \mu \mathrm{g} / \mathrm{kg}$ of betamethasone daily for $2 \mathrm{~d}$ before delivery had a higher rate of renal BBM vesicle $\mathrm{Na}^{+} / \mathrm{H}^{+}$antiporter activity and renal $\mathrm{Na}^{+}-\mathrm{K}^{+}$ATPase activity than neonatal vehicle-treated controls (7). Using a similar protocol, we have found that proximal convoluted tubules from neonates whose mothers were treated with dexamethasone $2 \mathrm{~d}$ before delivery had a higher rate of volume absorption, bicarbonate transport, a more lumen-negative transepithelial potential difference, and higher rates of apical $\mathrm{Na}^{+} / \mathrm{H}^{+}$ antiporter and basolateral $\mathrm{Na}\left(\mathrm{HCO}_{3}\right)_{3}$ symporter activity than control neonates (2). The purpose of the present study was to examine whether glucocorticoids potentially play a role in the maturational decrease in renal phosphate transport.

\section{MATERIALS AND METHODS}

Animals. New Zealand White rabbit pregnant does were housed at our institution for at least $6 \mathrm{~d}$ before their expected date of delivery. Neonatal rabbits were cared for by their mothers. At 3-5 d of life they received either daily s.c. injections of dexamethasone $(10 \mu \mathrm{g} / 100 \mathrm{~g}$ body weight) or vehicle for $4 \mathrm{~d}$, including a dose $2 \mathrm{~h}$ before they were killed. Dexamethasone was dissolved in $150 \mathrm{mmol} / \mathrm{L} \mathrm{NaCl}$ and $2 \mathrm{mmol} / \mathrm{L} \mathrm{K}_{2} \mathrm{HPO}_{4}(\mathrm{pH}$, 7.5). Blood and urine samples were collected for measurement of serum and urine creatinine and phosphate for determination of fractional excretion of phosphate. 
$B B M$ vesicle isolation. Control and dexamethasone-treated neonatal rabbits were killed, and the kidneys were rapidly removed and placed in an ice-cold homogenizing buffer containing (in mmol/L) $150 \mathrm{KCl}, 16 \mathrm{~N}$-2-hydroxyethylpiperazine- $N^{\prime}$-2-ethanesulfonic acid (HEPES), $\mathrm{pH} 7.50$, with Tris. The cortex was isolated and homogenized with a Teflon-glass Potter Eljevhem homogenizer. BBM vesicles were then isolated by differential centrifugation and magnesium precipitation as previously described $(4,7,20,21)$. The final BBM vesicle fraction was resuspended in the above buffer at an approximate concentration of $10 \mathrm{mg} \mathrm{BBM}$ protein/mL for equilibrium binding studies. For transport studies, BBM were resuspended in a buffer containing (in mmol/L) 300 mannitol, 16 HEPES, titrated to $\mathrm{pH} 7.5$ with Tris. Protein was measured by the method of Lowry et al. (22) with crystalline BSA as the standard. To minimize the potential day-to-day variation in the BBM isolation procedure, we isolated BBM from the kidneys of control and dexamethasone-treated neonatal rabbits simultaneously each day. For each BBM sample the kidneys from two rabbits were pooled $(n=1)$.

$B B M$ enzyme activity measurements. The purity of each BBM preparation was determined by measurement of membranespecific enzyme activity, including alkaline phosphatase, $\gamma$-glutamyltransferase, and leucine aminopeptidase (BBM bound), and $\mathrm{Na}^{+}-\mathrm{K}^{+}-\mathrm{ATPase}$ (BLM bound) in cortical homogenate and BBM fractions using a Gilford Response spectrophotometer (CibaCorning, Oberlin, $\mathrm{OH}$ ) equipped with kinetic and temperature control unit, as we have previously described $(20,21)$. Alkaline phosphatase activity was measured by a kinetic assay monitoring the production of $p$-nitrophenolate from $p$-nitrophenyl phosphate at $405 \mathrm{~nm}$ and $37^{\circ} \mathrm{C} \mathrm{(23).} \mathrm{Leucine} \mathrm{aminopeptidase} \mathrm{activity}$ was measured by a kinetic assay that monitored the conversion of L-leucine-p-nitroanilide at $380 \mathrm{~nm}$ and $37^{\circ} \mathrm{C}(24) . \gamma$-Glutamyltransferase activity was measured by a kinetic assay monitoring the conversion of $\mathrm{L}-\gamma$-glutamyl-p-nitroanilide at $405 \mathrm{~nm}$ and $37^{\circ} \mathrm{C}(25) . \mathrm{Na}^{+}-\mathrm{K}^{+}$-ATPase activity was measured by a kinetic assay system coupling ATP hydrolysis to pyruvate kinase and lactate dehydrogenase and monitoring the use of NADH at $340 \mathrm{~nm}$ and $37^{\circ} \mathrm{C}(26)$. Enzyme activities are expressed as picomoles per minute per milligram cortical homogenate or BBM protein. Enrichment (specific activity in BBM fraction/specific activity in homogenate) was determined in each BBM preparation.

BBM transport activity measurements. Transport measurements were performed in freshly isolated BBM vesicles by radiotracer uptake followed by rapid Millipore filtration. All uptake measurements were performed in triplicate, and the uptake was calculated on the basis of specific activity determined in each experiment and expressed as picomoles of solute/time interval/ milligram BBM protein.

To measure $\mathrm{Na}^{+}$gradient-dependent ${ }^{32} \mathrm{P}$ uptake (Na-P $\mathrm{P}_{\mathrm{i}}$ cotransport), $10 \mu \mathrm{L}$ of $\mathrm{BBM}$ preloaded in an intravesicular buffer of $300 \mathrm{mmol} / \mathrm{L}$ mannitol, $16 \mathrm{mmol} / \mathrm{L} \mathrm{HEPES}, 10 \mathrm{mmol} / \mathrm{L}$ Tris, $\mathrm{pH} 7.50$, was vortex mixed at $25^{\circ} \mathrm{C}$ with $40 \mu \mathrm{L}$ of an extravesicular uptake buffer of $150 \mathrm{mmol} / \mathrm{L} \mathrm{NaCl}, 25 \mu \mathrm{mol} / \mathrm{L} \mathrm{K}_{2} \mathrm{H}^{32} \mathrm{PO}_{4}$, $16 \mathrm{mmol} / \mathrm{L}$ HEPES, $10 \mathrm{mmol} / \mathrm{L}$ Tris, $\mathrm{pH} 7.50$. Uptake after 10 $s$ (representing initial linear rate) was terminated by an ice-cold stop solution that consisted of $135 \mathrm{mmol} / \mathrm{L} \mathrm{NaCl}, 10 \mathrm{mmol} / \mathrm{L}$ $\mathrm{Na}$ arsenate, $16 \mathrm{mmol} / \mathrm{L}$ HEPES, $10 \mathrm{mmol} / \mathrm{L}$ Tris, $\mathrm{pH} 7.50$. To determine the $\mathrm{Na}^{+}$-independent (i.e. diffusive) $\mathrm{P}_{\mathrm{i}}$ uptake, 150 $\mathrm{mmol} / \mathrm{L} \mathrm{NaCl}$ was replaced with $150 \mathrm{mmol} / \mathrm{L}$ choline chloride. To determine whether the effect of dexamethasone on $\mathrm{Na}-\mathrm{P}_{i}$ cotransport was due to a difference in $\mathrm{V}_{\max }$ or the $\mathrm{Km}$ for $\mathrm{P}_{\mathrm{i}}$, we measured Na- $P_{i}$ uptake in the presence of extravesicular $P_{i}$ concentrations of $25-400 \mu \mathrm{mol} / \mathrm{L} \mathrm{K}_{2} \mathrm{HPO}_{4}$. Finally, to examine whether the effect of dexamethasone was specific for $\mathrm{Na}-\mathrm{P}_{i}$ cotransport, we also measured $\mathrm{Na}^{+}$gradient-dependent glucose and proline uptake by a method identical to that of $\mathrm{P}_{\mathrm{i}}$ uptake except in the presence of $25 \mu \mathrm{mmol} / \mathrm{L}\left[{ }^{3} \mathrm{H}\right]$ D-glucose or 25 $\mu \mathrm{mol} / \mathrm{L}\left[{ }^{3} \mathrm{H}\right]$ L-proline. A stop solution that consisted of 150 $\mathrm{mmol} / \mathrm{L} \mathrm{NaCl}, 0.25 \mathrm{mmol} / \mathrm{L}$ phloridzin, $16 \mathrm{mmol} / \mathrm{L}$ HEPES, $10 \mathrm{mmol} / \mathrm{L}$ Tris, pH 7.50 was used in these experiments.

$B B M$ phosphonoformic acid measurements. To determine whether the decrease in Na-P cotransport in dexamethasonetreated neonatal rabbits was associated with an alteration in the number of $\mathrm{Na}-\mathrm{P}_{\mathrm{i}}$ cotransport units, we measured $\mathrm{P}_{\mathrm{i}}$-protectable, $\mathrm{Na}^{+}$-dependent equilibrium binding of PFA (Na-PFA) by a slight modification of the method previously described $(20,27)$. Briefly, freshly isolated BBM vesicles were either 1 ) preloaded in a buffer consisting of $150 \mathrm{mmol} / \mathrm{L} \mathrm{NaCl}, 16 \mathrm{mmol} / \mathrm{L}$ HEPES, $10 \mathrm{mmol} /$ $\mathrm{L}$ Tris, pH 7.50, and binding was initiated by mixing $10 \mu \mathrm{L}$ of BBM with $40 \mu \mathrm{L}$ of binding solution of same composition also containing $25 \mu \mathrm{mol} / \mathrm{L}\left[{ }^{14} \mathrm{C}\right] \mathrm{PFA}$ (New England Nuclear, Boston, MA; sp act $30 \mathrm{mCi} / \mathrm{mmol} / \mathrm{L}$ ), or 2) preloaded in a buffer of identical osmolality consisting of $100 \mathrm{mmol} / \mathrm{L} \mathrm{NaCl}, 25 \mathrm{mmol} /$ L Na${ }_{2} \mathrm{HPO}_{4}, 12.5 \mathrm{mmol} / \mathrm{L}$ choline chloride, $16 \mathrm{mmol} / \mathrm{L}$ HEPES, $10 \mathrm{mmol} / \mathrm{L}$ Tris, $\mathrm{pH} 7.50$, and binding was initiated by mixing $10 \mu \mathrm{L}$ of BBM with $40 \mu \mathrm{L}$ of binding solution of same composition also containing $25 \mu \mathrm{mol} / \mathrm{L}\left[{ }^{14} \mathrm{C}\right] \mathrm{PFA}$.

In preliminary studies we determined that maximal (equilibrium) binding of $\left[{ }^{14} \mathrm{C}\right] P F A$ occurred at $30 \mathrm{~min}$. Thus, we performed all the binding studies after $30 \mathrm{~min}$ incubation at $25^{\circ} \mathrm{C}$. Binding was assayed after diluting and washing the unbound radioactivity by the addition of an ice-cold solution containing $150 \mathrm{mmol} / \mathrm{L} \mathrm{NaCl}, 16 \mathrm{mmol} / \mathrm{L}$ HEPES, $10 \mathrm{mmol} / \mathrm{L}$ Tris, $\mathrm{pH}$ 7.50. $\mathrm{P}_{\mathrm{i}}$-protectable Na-PFA binding is determined as the difference in PFA binding in 1) the absence of $\mathrm{P}_{i}$ and 2) presence of excess $P_{i}$, and it is expressed as pmol $\left[{ }^{14} \mathrm{C}\right] \mathrm{PFA} / 30 \mathrm{~min} / \mathrm{mg} \mathrm{BBM}$ protein.

BBM lipid fluidity measurements. To determine whether the decrease in $\mathrm{Na}-\mathrm{P}_{i}$ cotransport in dexamethasone-treated rabbits was associated with alterations in membrane lipid fluidity, BBM were isolated from control and dexamethasone-treated neonatal rabbit kidneys and fluidity was measured with fluorescence techniques. Steady-state fluorescence anisotropy of DPH $\left(\mathrm{r}_{\mathrm{DPH}}\right)$ and TMA-DPH ( $\mathrm{r}_{\mathrm{TMA}-\mathrm{DPH}}$ ) were measured in a spectrofluorometer (SLM 4800C, Urbana, IL) equipped with excitation and emission polarizers as we have previously described $(20,21)$. Briefly, 0.1 mg BBM protein was resuspended in $150 \mathrm{mmol} / \mathrm{L} \mathrm{NaCl}, 16$ $\mathrm{mmol} / \mathrm{L}$ HEPES, $10 \mathrm{mmol} / \mathrm{L}$ Tris, $\mathrm{pH} 7.50$ buffer, and DPH or TMA-DPH were added from a stock solution to result in a probe/lipid ratio of 1:360. Excitation wavelength was $360 \mathrm{~nm}$, and emission was viewed through a KV $399 \mathrm{~nm}$ filter. $\mathrm{r}_{\mathrm{DPH}}$ and $\mathbf{r}_{\mathrm{TMA}-\mathrm{DPH}}$ were determined by

$$
r=\frac{I_{I I}-I_{I}}{I_{l l}+2 I_{I}}
$$

where $I_{11}$ and $I_{1}$ represent the intensities of the parallel and perpendicular components of the emission, respectively. The parameter $r_{D P H}$ or $r_{T M A}$-DPH reflects the degree to which the rotation of DPH or TMA-DPH molecules embedded in BBM are hindered and provides an index that is inversely related to membrane lipid fluidity. Of note, the term membrane lipid fluidity is used here to denote the structural and dynamic properties that determine the relative motions and order of lipid molecules in the membrane.

$B B M$ lipid composition determination. Total lipids in $1 \mathrm{mg}$ BBM protein were extracted twice and evaporated under nitrogen as previously described (28). The sample was resuspended in chloroform and divided into aliquots for measurement of cholesterol, total phospholipids, and individual phospholipid content. The cholesterol sample was evaporated to residue, resuspended in hexane, and injected into a $530-\mu \mathrm{m} 50 \%$ phenylmethyl silicone column (Hewlett-Packard, Palo Alto, CA) in a HewlettPackard model 5890 gas chromatograph with flame ionization detector run isothermally at $280^{\circ} \mathrm{C}$. Coprostenol (Supelco, Bellefonte, PA) served as the internal standard. The areas were computed with a Hewlett Packard 3392A integrator, and the cholesterol content was expressed as nanomoles per milligram 
BBM protein $(21,29)$. The sample for total phospholipid determination was dried to residue and resuspended in chloroform. The total phospholipid content was determined by measuring the phosphorus content as described by Ames and Dubin (30). Individual phospholipids were isolated by thin-layer chromatography. The sample was placed onto Kieselgel Silica Gel 60 precoated thin-layer chromatography plates (Merck, Darmstadt, Germany). The plates were developed in two dimensions. The first solvent was chloroform/methanol/acetic acid (65:25:10 vol/ vol), and the second was chloroform/ethanol/88\% formic acid (65:25:10 vol/vol). The chromatograms were allowed to dry and were then exposed to iodine. The individual phospholipids were well separated, and their location was compared with standards (Supelco, Bellefonte, PA). Areas of the silica gel containing phospholipids were scraped into acid-washed tubes, and the phospholipids were extracted from the silica gel (29). The silica gel was removed by centrifugation, and the phospholipids were separated into the chloroform phase. The sample was dried, and the phospholipid content was determined (30). Total phospholipid content was expressed as nanomoles per milligram BBM protein, and individual phospholipids were expressed as mol\% of total phospholipid content.

Statistical analysis. All data are expressed as means \pm SEM. Unpaired $t$ test was used to compare results between control and dexamethasone-treated neonatal rabbits. Significance was accepted at $p<0.05$.

\section{RESULTS}

Effect of dexamethasone on fractional excretion of phosphate. Dexamethasone administration for 4 consecutive $d$ resulted in a significant increase in the fractional excretion of phosphate [0.4 \pm 0.2 in control versus $13.7 \pm 3.7 \%$ in dexamethasone-treated neonates $(p<0.01)]$.

Effect of dexamethasone on BBM enrichment and enzyme activity. BBM isolated from control and dexamethasone-treated neonates were equally enriched, 8- to 10 -fold, as assessed by the activities of BBM-specific enzymes. Cross contamination with BLM was minimal and similar, as assessed by the activity of the BLM-specific enzyme $\mathrm{Na}^{+}-\mathrm{K}^{+}$-ATPase (Table 1). Dexamethasone administration resulted in significant increases in the activities of alkaline phosphatase (BBM bound) and $\mathrm{Na}^{+}-\mathrm{K}^{+}-\mathrm{ATP}-$ ase (BLM bound), whereas leucine aminopeptidase and $\gamma$-glutamyltransferase activities were not changed (Table 1).

Effect of dexamethasone on BBM transport activity. Dexamethasone treatment caused a significant decrease in BBM Na$P_{i}$ cotransport activity [50.8 \pm 3.6 in control versus $29.2 \pm 2.6$ $\mathrm{pmol}{ }^{32} \mathrm{P}_{\mathrm{i}} / 10 \mathrm{~s} / \mathrm{mg}$ BBM protein in dexamethasone-treated neonates $(p<0.001)$ ] (Table 2). No significant difference was seen in $\mathrm{Na}$-independent $\mathrm{P}_{\mathrm{i}}$ transport $(7.1 \pm 1.6$ in control versus 4.9

Table 1. Effect of dexamethasone on membrane enzymes

\begin{tabular}{lccc}
\hline & Control & Dexamethasone $p$ value \\
\hline Alkaline phosphatase & & & \\
Cortical homogenate & $188.3 \pm 12.3$ & $310.3 \pm 25.7$ & $<0.001$ \\
BBM & $1522.7 \pm 59.9$ & $2959.9 \pm 243.9$ & $<0.001$ \\
Enrichment & $8.2 \pm 0.3$ & $9.6 \pm 0.3$ & $<0.005$ \\
Leucine aminopeptidase & & & \\
Cortical homogenate & $66.5 \pm 2.8$ & $54.4 \pm 5.4$ & NS \\
BBM & $592.4 \pm 98.3$ & $497.5 \pm 28.8$ & NS \\
Enrichment & $8.9 \pm 1.1$ & $9.2 \pm 0.4$ & NS \\
$\gamma$-Glutamyltransferase & & & \\
Cortical homogenate & $316.7 \pm 29.0$ & $308.8 \pm 26.4$ & NS \\
BBM & $2615.5 \pm 258.8$ & $2632.3 \pm 157.2$ & NS \\
Enrichment & $8.3 \pm 0.4$ & $8.7 \pm 0.3$ & NS \\
Na ${ }^{+}-K^{+}$-ATPase & & & \\
Cortical homogenate & $77.7 \pm 16.2$ & $145.9 \pm 19.8$ & $<0.025$ \\
BBM & $80.0 \pm 12.4$ & $196.9 \pm 23.1$ & $<0.005$ \\
Enrichment & $1.3 \pm 0.3$ & $1.5 \pm 0.3$ & NS \\
\hline
\end{tabular}

Table 2. Effect of dexamethasone on Na-P $P_{\mathrm{i}}, \mathrm{Na}$-glucose, and Na-proline transport in $B B M$ vesicles from neonatal rabbits

\begin{tabular}{|c|c|c|}
\hline & Control & Dexamethasone \\
\hline $\begin{array}{l}\mathrm{Na}-\mathrm{P}_{\mathrm{i}}\left(\mathrm{pmol}{ }^{32} \mathrm{P} / 10 \mathrm{~s} / \mathrm{mg} \text { pro- }\right. \\
\text { tein) }\end{array}$ & $50.8 \pm 3.6$ & $29.2 \pm 2.6^{*}$ \\
\hline $\begin{array}{l}\text { Na-glucose (pmol }{ }^{3} \mathrm{H} \text { glucose/ } \\
10 \mathrm{~s} / \mathrm{mg} \text { protein) }\end{array}$ & $31.4 \pm 3.3$ & $51.3 \pm 5.1 \dagger$ \\
\hline $\begin{array}{l}\text { Na-proline (pmol }{ }^{3} \mathrm{H} \text { proline/ } \\
10 \mathrm{~s} / \mathrm{mg}^{2} \text { protein) }\end{array}$ & $25.0 \pm 3.2$ & $41.2 \pm 4.0 \dagger$ \\
\hline
\end{tabular}

$* p<0.001$ vs control.

$+p<0.05$ vs control.

$\pm 0.8 \mathrm{pmol}{ }^{32} \mathrm{P}_{\mathrm{i}} / 10 \mathrm{~s} / \mathrm{mg} \mathrm{BBM}$ protein in dexamethasone-treated neonates).

BBM transport studies in the presence of $25-400 \mu \mathrm{mol} / \mathrm{L}$ extravesicular $\mathrm{P}_{\mathrm{i}}$ demonstrated that in dexamethasone-treated neonates the decrease in $\mathrm{Na}-\mathrm{P}_{\mathrm{i}}$ cotransport was mediated by a decrease in the $V_{\max }[769 \pm 21$ in control versus $401 \pm 30$ pmol ${ }^{32} \mathrm{P}_{\mathrm{i}} / 10 \mathrm{~s} / \mathrm{mg}$ BBM protein in dexamethasone group $(p<0.01)]$. No change was observed in the affinity $(\mathrm{Km})$ for $\mathrm{P}_{\mathrm{i}}$ [146 \pm 9 in control neonates versus $142 \pm 25 \mu \mathrm{mol} / \mathrm{L} \mathrm{P}_{\mathrm{i}}$ in dexamethasone-treated neonates $(p=N S)]$. These data are shown in Figure 1.

In contrast to the inhibition of $\mathrm{Na}-\mathrm{P}_{\mathrm{i}}$ cotransport, dexamethasone caused significant increases in Na-glucose [31.4 \pm 3.3 in control neonates versus $51.3 \pm 5.1 \mathrm{pmol}{ }^{3} \mathrm{H}$ glucose $/ 10 \mathrm{~s} / \mathrm{mg}$ BBM protein in dexamethasone-treated neonates $(p<0.05)$ ] (Table 2) and Na-proline cotransport [25.0 \pm 3.2 in control neonates versus $41.2 \pm 4.0 \mathrm{pmol}{ }^{3} \mathrm{H}$ proline $/ 10 \mathrm{~s} / \mathrm{mg}$ BBM protein in dexamethasone-treated neonates $(p<0.05)$ ] (Table 2).

Effect of dexamethasone on BBM $P_{\mathrm{i}}$-protectable Na-PFA binding. Dexamethasone treatment caused no changes in total (results not shown) or $P_{i}$-protectable Na-PFA binding [7.4 \pm 1.2 in control versus $7.7 \pm 0.6 \mathrm{pmol}\left[{ }^{14} \mathrm{C}\right] \mathrm{PFA} / 30 \mathrm{~min} / \mathrm{mg}$ BBM protein in dexamethasone $(p=\mathrm{NS})]$. These results suggest that dexamethasone treatment does not cause an alteration in BBM Na$P_{i}$ cotransporter number (27).

Effect of dexamethasone on BBM fluidity. Dexamethasone treatment caused significant increases in the fluorescence anisotropy of DPH [0.214 \pm 0.003 in control versus $0.222 \pm 0.002$ in dexamethasone group $(p<0.05)]$ and TMA-DPH $[0.253 \pm$ 0.001 in control versus $0.257 \pm 0.001$ in dexamethasone group $(p<0.05)$ ]. These results suggest that dexamethasone treatment caused a decrease in BBM fluidity.

Effect of dexamethasone on BBM lipid composition. Dexamethasone treatment caused no change in BBM cholesterol or total phospholipid content. A significant decrease occurred in sphingomyelin, and a significant increase occurred in both phosphatidylcholine and phosphatidylinositol in BBM (Table 3).

\section{DISCUSSION}

The present study examined whether glucocorticoids are a potential factor to explain the maturational decrease in renal phosphate transport. The data demonstrate that dexamethasonetreated neonatal rabbits had a significant increase in fractional excretion of phosphate compared with control neonates. BBM vesicles from dexamethasone-treated neonates had a significantly lower rate of $\mathrm{Na}-\mathrm{P}_{i}$ transport, which was due to a decrease in the $V_{\max }$ with no change in the $\mathrm{Km}$ of the transporter for $\mathrm{P}_{\mathrm{i}}$. This decrease in $V_{\max }$ was not mediated by a change in the number of transporters as assessed by $\mathrm{P}_{\mathrm{i}}$-protectable Na-PFA binding but was associated with an alteration in membrane fluidity and with changes in BBM phospholipid content.

Roberts and Pitts (31) first demonstrated that glucocorticoids inhibit the maximal tubular reabsorption of phosphate in normal and adrenalectomized dogs. Subsequent studies have shown that the phosphaturic effect of glucocorticoids was independent of 


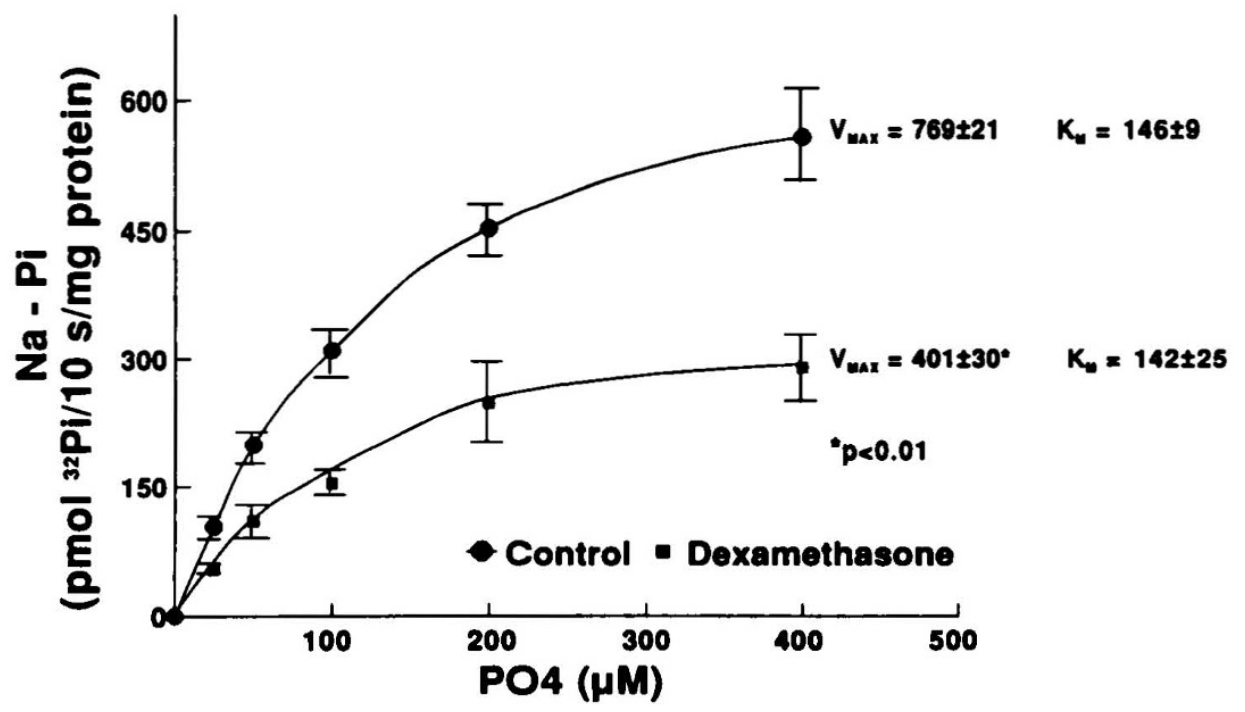

Fig. 1. Effect of dexamethasone on Na-P, transport kinetics.

Table 3. Effect of dexamethasone on BBM composition*

\begin{tabular}{lccccccc}
\hline & Cholesterol & $\begin{array}{c}\text { Total } \\
\text { phospholipid }\end{array}$ & SPH & PC & PE & PS & PI \\
\hline Control & $349 \pm 22$ & $499 \pm 19$ & $25.3 \pm 1.0$ & $33.9 \pm 1.1$ & $26.0 \pm 1.4$ & $10.8 \pm 0.8$ & $3.9 \pm 0.2$ \\
DEX & $332 \pm 14$ & $499 \pm 8$ & $22.0 \pm 0.7 \dagger$ & $37.0 \pm 1.0 \dagger$ & $25.9 \pm 0.3$ & $10.6 \pm 0.9$ & $4.6 \pm 0.2+$ \\
\hline
\end{tabular}

*Values are means \pm SEM. Cholesterol and total phospholipid content are expressed as nanomoles per milligram BBM protein. Individual phospholipids are expressed as molar percentage of total phospholipid content. SPH. sphingomyelin: PC. phosphatidylcholine: PE, phosphatidylethanolamine: PS, phosphatidylserine; PI, phosphatidylinositol: DEX, dexamethasone.

$+p<0.05$ vs control.

parathyroid hormone (32-34) and the filtered load of phosphate $(32,34)$. The rate of Na- $\mathrm{P}_{\text {i }}$ uptake in renal $\mathrm{BBM}$ vesicles from adult rats who received glucocorticoids is slower than control rats $(34,35)$. The inhibitory effect of glucocorticoids on $\mathrm{Na}$ dependent phosphate uptake was due to a decrease in $\mathrm{V}_{\max }$ with no change in the $\mathrm{Km}$ for $\mathrm{P}_{\mathrm{i}}(34)$. More recently, studies have demonstrated that glucocorticoids have a direct renal epithelial action in vitro to inhibit phosphate transport $(36,37)$. The direct inhibitory effect of glucocorticoids on Na-dependent $P_{i}$ uptake in cultured chick renal cells was blocked by inhibitors of RNA and protein synthesis (36). The present study demonstrates that neonates have a similar response to glucocorticoids as do adult animals. Control neonates had virtually no phosphate in their urine, unlike the animals receiving dexamethasone. Renal BBM vesicles from dexamethasone-treated neonates had a lower rate of Na-dependent phosphate uptake, which was due to a lower $\mathrm{V}_{\max }$ with no change in the $\mathrm{Km}$ for phosphate. The glucocorticoid-induced changes in membrane fluidity and lipid composition in our study may depend on RNA and protein synthesis in vivo. This possibility will require further investigation.

Previous studies have examined the effect of glucocorticoids on renal glucose transport. Na-dependent glucose transport in renal BBM vesicles from glucocorticoid-treated adult animals was no different than control adult animals $(34,35)$. Neonatal proximal tubules have a lower rate of glucose $(3,4)$ and proline (38) transport than adult proximal tubules. Although prenatal administration of glucocorticoids has been shown to accelerate the maturation of the renal apical $\mathrm{Na}^{+} / \mathrm{H}^{+}$antiporter $(2,7)$, basolateral $\mathrm{Na}\left(\mathrm{HCO}_{3}\right)_{3}$ symporter $(2)$, and basolateral $\mathrm{Na}^{+}-\mathrm{K}^{+}-$ ATPase activity $(1,8-10)$, it had no effect on glucose transport $(2,7)$. In the present study, we measured Na-dependent glucose and proline transport as a control to determine whether there was a nonspecific inhibition in BBM transport in dexamethasone-treated neonates. Surprisingly, the rate of glucose and proline uptake were significantly higher in BBM vesicles from dexamethasone-treated neonates.
Previous studies have demonstrated that changes occur in the physical properties of the renal BBM with maturation $(4,39$, $40)$. In both the rabbit $(4)$ and rat $(38,40)$ an increase occurs in the fluorescence anisotropy of DPH (i.e. a decrease in membrane fluidity) in adult as compared with neonatal renal BBM. This change in membrane fluidity may play a role in maturational changes in membrane transport (39). In a previous study from our laboratory, we enriched the cholesterol content of BBM vesicles (20). An increase in cholesterol content of 12 and $24 \%$ resulted in a progressive decrease in BBM fluidity. This decrease in membrane fluidity was accompanied by a parallel decrease in $\mathrm{Na}^{+}$-dependent $\mathrm{P}_{i}$ uptake. $\mathrm{A}$ decrease in membrane fluidity did not affect Na-glucose, Na-proline, and $\mathrm{Na}-\mathrm{H}$ antiporter activity.

Evidence exists, however, that changes in membrane fluidity are not specific for phosphate transport. Other laboratories have found that increasing membrane fluidity by the addition of benzyl alcohol resulted in an increase in phosphate transport but a decrease in Na-glucose cotransport $(41,42)$. In addition, whereas butanol, hexanol, and heptanol all increase renal BBM fluidity, heptanol and hexanol had no effect and butanol decreased phosphate transport (43). Each alcohol lowered $\mathrm{Na}$ proline transport. Thus, the glucocorticoid-induced decrease in membrane fluidity in our study may not be the cause for the decrease in phosphate transport.

In the present study we found that renal BBM from dexamethasone-treated neonates had a decrease in fluidity, a decrease in sphingomyelin, and an increase in phosphatidylcholine and phosphatidylinositol content. Membrane fluidity is determined by a number of factors, including protein-lipid interactions, cholesterol/phospholipid molar ratio, saturated/unsaturated acid molar ratio, sphingomyelin/phosphatidylcholine molar ratio, and glycolipid content. Although the decrease in sphingomyelin/ phosphatidylcholine ratio observed after dexamethasone administration in our study is usually associated with an increase in membrane fluidity, this result is dependent on the fatty acid composition of the sphingomyelin and phosphatidylcholine (44). 
A previous study has compared the lipid composition in intestinal BBM in suckling and weaned rats (45). Intestinal maturation was associated with a decrease in membrane fluidity accompanied by a decrease in sphingomyelin/phosphatidylcholine molar ratio. The maturational differences in membrane lipid fluidity were no longer observed in lipid extracts from these membranes, indicating that protein-lipid interactions, rather than lipid composition per se, mediated the maturational differences in membrane fluidity.

In the present study we found that administration of dexamethasone to neonatal rabbits resulted in a decrease in Nadependent phosphate uptake in renal BBM vesicles. The dexamethasone-induced inhibition was due to a decrease in the $\mathrm{V}_{\max }$ with no change in the $\mathrm{Km}$ for $\mathrm{P}_{\mathrm{i}}$. No change occurred in phosphate-protectable Na-PFA binding. Although PFA has been shown to bind to other anion cotransporters and thus may only be an approximation of the density of phosphate transporters (46), our results suggest that dexamethasone does not affect $\mathrm{Na}$ phosphate transporter density and affinity. The inhibition in phosphate transport was accompanied by a reduction in BBM fluidity and alteration in individual phospholipid composition, with no change in either cholesterol or total phospholipid content. Conclusions about the role of glucocorticoids in renal maturation from studies using pharmacologic doses of dexamethasone must be made with caution. Similar changes in phosphate transport with glucocorticoids are observed in adult animals (but not glucose and proline transport), and thus the direct role of glucocorticoids in maturation of phosphate transport remains speculative. Whether physiologic changes in glucocorticoid concentration in neonatal animals are associated with changes in phosphate transport and BBM composition and fluidity cannot be and were not directly addressed. However, our data suggest that glucocorticoids may play a role in the postnatal decrease in renal phosphate transport.

Acknowledgments. The authors thank Danny Gentry, Paul Wilson, and Shelly Scott for their able technical assistance and Janell McQuinn for typing the manuscript.

\section{REFERENCES}

1. Aperia A, Larsson L 1984 Induced development of proximal tubular Na-KATPase, basolateral cell membranes and fluid reabsorption. Acta Physio Scand 121:133-141

2. Baum M, Quigley R 1991 Prenatal glucocorticoids stimulate neonatal juxtamedullary proximal convoluted tubule acidification. Am $\mathrm{J}$ Physiol 261:F746-F752

3. Schwartz GJ, Evan AP 1983 Development of solute transport in rabbit proximal tubule. I. $\mathrm{HCO}_{2}^{-}$and glucose absorption. Am J Physiol 245:F382-F390

4. Beck JC, Lipkowitz MS, Abramson RG 1990 Characterization of the fetal glucose transporter in rabbit kidney. J Clin Invest 82:379-387

5. Baum M 1990 Neonatal rabbit juxtamedullary proximal convoluted tubule acidification. J Clin Invest 85:499-506

6. Baum M 1992 Developmental changes in rabbit juxtamedullary proximal convoluted tubule acidification. Pediatr Res 31:411-414

7. Beck JC, Lipkowitz MS, Abramson RG 1991 Ontogeny of $\mathrm{Na} / \mathrm{H}$ antiporter activity in rabbit renal BBM vesicles. J Clin Invest 87:2067-2076

8. Aperia A, Larsson L, Zetterström R 1981 Hormonal induction of Na-KATPase in developing proximal tubular cells. Am J Physiol 241:F356-F360

9. Schmidt U, Horster M 1977 Na-K-activated ATPase: activity maturation in rabbit nephron segments dissected in vitro. Am J Physiol 233:F55-F60

10. Schwartz GJ, Evan AP 1984 Development of solute transport in rabbit proximal tubule. III. Na-K-ATPase activity. Am J Physiol 246:F845-F852

11. Brodehl J, Gellissen K, Weber H-P 1981 Postnatal development of tubular phosphate reabsorption. Clin Nephrol 17:163-171

12. Caverzasio J, Bonjour J-P, Fleisch $\mathbf{H} 1982$ Tubular handling of $P_{i}$ in young growing and adult rats. Am J Physiol 242:F705-F710

13. Haramati A, Mulroney SE, Webster SK 1988 Developmental changes in the tubular capacity for phosphate reabsorption in the rat. Am J Physiol 255:F287-F291

14. Mulroney SE, Haramati A 1990 Renal adaptation to changes in dietary phosphate during development. Am J Physiol 258:F1650-F1656

15. Johnson V, Spitzer A 1986 Renal reabsorption of phosphate during development: whole-kidney events. Am J Physiol 251:F251-F256
16. Neiberger RE, Barac-Nieto M, Spitzer A 1989 Renal reabsorption of phosphate during development: transport kinetics in BBMV. Am J Physiol 257:F268F274

17. Henning SJ 1978 Plasma concentrations of total and free corticosterone during development in the rat. Am J Physiol 235:E451-E456

18. Hummelink R, Ballard PL 1986 Endogenous corticoids and lung development in the fetal rabbit. Endocrinology 118:1622-1629

19. Malinowska KW, Hardy RN, Nathanielsz PW 1972 Plasma adrenocorticosteroid concentrations immediately after birth in the rat, rabbit and guinea-pig. Experientia 28:1366-1367

20. Levi M, Baird BM, Wilson PV 1990 Cholesterol modulates rat renal BBM phosphate transport. J Clin Invest 85:231-237

21. Levi M, Jameson DM, van der Meer BW 1989 Role of BBM lipid composition and fluidity in impaired renal $P_{i}$ transport in aged rat. Am J Physiol 256:F85F94

22. Lowry OH, Rosebrough NJ, Farr AL, Randall RJ 1951 Protein measurements with the Folin phenol reagent. J Biol Chem 193:265-275

23. Bessey OA, Lowry OH, Brock MJ 1964 A method for the rapid determination of alkaline phosphatase with five cubic millimeters of serum. J Biol Chem 164:321-329

24. Haasa W, Schafer A, Murer H, Kinne R 1979 Studies on the orientation of BBM vesicles. Biochem J 172:57-62

25. Tate SS, Meister A 1974 Interaction of $\gamma$-glutamyl transpeptidase with amino acids, dipeptides, and derivatives and analogs of glutathione. J Biol Chem 249:7593-7602

26. Schoner W, von Illberg C, Kramer R $1967 \mathrm{On}$ the mechanism of $\mathrm{Na}^{+}$- and $\mathrm{K}^{+}$-stimulated hydrolysis of adenosine triphosphate. Eur J Biochem 1:334343

27. Hoppe A, Jiann-Trzuo L, Onsgard M, Knox FG, Dousa TP 1991 Quantitation of the $\mathrm{Na}^{+}-\mathrm{P}_{i}$ cotransporter in renal cortical BBMs. $\left[{ }^{14} \mathrm{C}\right] \mathrm{Phosphonoformic}$ acid as a useful probe to determine the density and its change in response to parathyroid hormone. J Biol Chem 266:11528-11536

28. Bligh EG. Dyer WJ 1959 A rapid method of total lipid extraction and purification. Can J Biochem Physiol 37:911-917

29. Levi M, Molitoris BA, Burke TJ, Schrier RW, Simon FR 1987 Effects of vitamin D-induced chronic hypercalcemia on rat renal cortical plasma membranes and mitochondria. Am J Physiol 252:F267-F275

30. Ames BN, Dubin DR 1960 The role of polyamines in the neutralization of bacteriophage deoxyribonucleic acid. J Biol Chem 235:769-775

31. Roberts KE, Pitts RF 1953 The effects of cortisone and desoxycorticosterone on the renal tubular reabsorption of phosphate and the excretion of titratable acid and potassium in dogs. Endocrinology 52:324-330

32. Durasin I, Frick A, Neuweg M 1984 Glucocorticoid-induced inhibition of the reabsorption of inorganic phosphate in the proximal tubule in the absence of parathyroid hormone. Renal Physiol Biochem 7:115-123

33. Frick A, Durasin I, Neuweg M 1981 Phosphaturic response of hydrocortisone in the presence and the absence of parathyroid hormone. Pflugers Arch 392:99-105

34. Turner ST, Kiebzak GM, Dousa TP 1982 Mechanism of glucocorticoid effect on renal transport of phosphate. Am J Physiol 243:C227-C236

35. Freiberg JM, Kinsella J, Sacktor B 1982 Glucocorticoids increase the $\mathrm{Na}^{+}-\mathrm{H}^{+}$exchange and decrease the $\mathrm{Na}^{+}$gradient-dependent phosphateuptake systems in renal BBM vesicles. Proc Natl Acad Sci USA 79:49324936

36. Noronha-Blob L, Sacktor B 1985 Inhibition of glucocorticoids of phosphate transport in primary cultured renal cells. J Biol Chem 261:2164-2169

37. Poujeol P, Vandewalle A 1985 Phosphate uptake by proximal cells isolated from rabbit kidney: role of dexamethasone. Am J Physiol 249:F74-F83

38. Medow MS, Roth KS, Goldmann DR, Ginkinger K, Hsu BYL, Segal S 1986 Developmental aspects of proline transport in rat renal BBMs. Proc Natl Acad Sci USA 83:7561-7564

39. Medow MS, Segal S 1987 Age related changes in fluidity of rat renal BBM vesicles. Biochem Biophys Res Commun 142:849-856

40. Hise MK, Weinman EJ 1986 Physical properties of the rat renal BBM during growth. Pflugers Arch 406:234-236

41. Friedlander G, Shahedi M, Grimellec CL, Amiel C 1988 Increase in membrane fluidity and opening of tight junctions have similar effects on sodium-coupled uptakes in renal epithelial cells. J Biol Chem 263:11183-11188

42. Yusufi ANK, Szczepanska-Konkel M, Hoppe A, Dousa TP 1989 Different mechanisms of adaptive increase in $\mathrm{Na}^{+}-\mathrm{P}_{i}$ cotransport across renal BBM. Am J Physiol 256:F852-F861

43. Levine BS, Knibloe KA, Golchini K, Hashimoto S, Kurtz I 1991 Renal adaptation to dietary phosphate deprivation: role of proximal tubule BBM fluidity. Am J Physiol 260:F613-F618

44. van Blitterswijk WJ, van der Meer BW, Hilkmann H 1987 Quantitative contributions of cholesterol and the individual classes of phospholipids and their degree of fatty acyl (un)saturation to membrane fluidity measured by fluorescence polarization. Biochemistry 26:1746-1756

45. Schwarz SM, Hostetler B, Ling S, Mone M, Watkins JB 1985 Intestinal membrane lipid composition and fluidity during development in the rat. Am J Physiol 248:G200-G207

46. Tenenhouse HS, Lee $\mathrm{J} 1990$ Sulfate inhibits $\left[{ }^{14} \mathrm{C}\right]$ phosphonoformic acid binding to renal BBMs. Am J Physiol 259:F286-F292 